\title{
Filtration and resuspension of particulate matter and phytoplankton on an intertidal mussel bed in the Oosterschelde estuary (SW Netherlands)
}

\author{
T. C. Prins ${ }^{1, *}$, A. C. Smaal ${ }^{2}$, A. J. Pouwer ${ }^{1}$, N. Dankers ${ }^{3}$ \\ ${ }^{1}$ Netherlands Institute of Ecology, Centre for Estuarine and Coastal Ecology, PO Box 140, 4400 AC Yerseke, The Netherlands \\ ${ }^{2}$ National Institute for Coastal and Marine Management/RIKZ, PO Box 8039, 4330 EA Middelburg, The Netherlands \\ ${ }^{3}$ DLO Institute for Forestry and Nature Research, PO Box 167, 1790 AD Den Burg Texel, The Netherlands
}

\begin{abstract}
In situ measurements were carried out on an intertidal mussel bed in the Oosterschelde estuary, SW Netherlands. Exchange of suspended particulate matter and phytoplankton between the water column and the mussel bed was measured with a Benthic Ecosystem Tunnel. In situ clearance rates of the mussel bed were compared to clearance rates of individual mussels measured in a field station under ambient conditions. Concentrations of suspended particulate matter (SPM) and particulate organic carbon (POC) in the water column above the tidal flat were affected by wind-induced resuspension. Chlorophyll a concentrations were higher during flood tides than during ebb tides, and were not affected by wind-induced resuspension. Clearance rates of the mussel bed ranged from 1.3 to $7.1 \mathrm{~m}^{3} \mathrm{~m}^{-2} \mathrm{~h}^{-1}$. In situ measured clearance rates generally were comparable to rates observed in measurements with individual mussels in a field station. Uptake of SPM and POC by the mussel bed was highly variable. Under calm weather conditions, uptake rates were correlated with inflow concentrations. Net uptake of phytoplankton was relatively higher than the uptake of POC, indicating that a major part of the POC was resuspended and exported from the mussel bed after filtration. In addition, wind stress induced considerable resuspension and export of SPM and POC from the mussel bed. Chlorophyll a uptake was less influenced by wind, and high rates of uptake, caused by mussel filtration, were observed. The result of filtration and resuspension processes was a net uptake by the mussel bed of particulate matter containing a relatively high proportion of phytoplankton: the mussel bed acted as a selective filter for phytoplankton.
\end{abstract}

KEY WORDS: Bivalves · Phytoplankton - In situ measurements · Particulate matter flux · Wind

\section{INTRODUCTION}

Bivalve suspension feeding may have a considerable impact on benthic-pelagic coupling in estuarine and coastal ecosystems (Dame 1993). In estuaries with high densities of bivalves, these suspension feeders have the potential to filter the entire volume in a few days (see Smaal \& Prins 1993 for review), and control of phytoplankton biomass by grazing is likely. Many observations of low phytoplankton concentrations have been related to high bivalve grazing pressure (e.g. Cadée \& Hegeman 1974, Cloern 1982, Carlson et al. 1984, Nichols 1985, Smaal et al. 1986, Hily 1991). In addition, the activity of the bivalves may significantly

·E-mail: prins@rikz.rws.minvenw.nl increase the sedimentation of particulate organic material (Verwey 1952, Haven \& Morales-Alamo 1972).

Most of the hypotheses concerning the impact of bivalve feeding on the pelagic system are based on the extrapolation of individual rates of filtration of bivalves to the scale of an estuary. However, scaled-up bivalve grazing rates, estimated from laboratory measurements with algal diets, may severely overestimate in situ filtration rates (Doering \& Oviatt 1986). In addition, extrapolations are seldom based on data on seston concentration and composition in the feeding zone of the bivalve population. Several in situ studies have been carried out on oyster reefs and mussel beds using tunnels or flumes. The main characteristic of these in situ methods is that vertical and/or horizontal advective 
transport of seston particles is prevented, thus enabling the detection of concentration changes due to bivalve filtration. The use of tunnels or flumes enables the study of bivalve activity under ambient conditions of food supply, bivalve density and abiotic factors like current speed. These in situ studies have shown that fluxes of suspended particulate matter often display an erratic pattern of uptake and release, whereas a consistent uptake of phytoplankton by the mussel bed is observed (Dame et al. 1984, 1989, 1991, Dame \& Dankers 1988, Asmus et al. 1990, Asmus \& Asmus 1991). Release of particulate matter by the bivalve bed has been related to resuspension caused by high current velocities or wind-induced turbulence (Dame et al. 1989, Asmus et al. 1990). From these in situ observations it can be inferred that laboratory data on clearance rates of bivalves may be of limited value for the estimation of particulate matter fluxes from the water column to the benthic system. Scaled-up values of bivalve grazing rates only represent a potential impact on the water column, as resuspension and interactions between the bivalves are not taken into account.

As part of an ecosystem study (Nienhuis \& Smaal 1994), in situ measurements of material exchange between the water column and an intertidal bed of the blue mussel Mytilus edulis were carried out in the Oosterschelde estuary, SW Netherlands. In this estuary the blue mussel is very abundant and may greatly affect phytoplankton concentrations (Smaal et al. 1986, Herman \& Scholten 1990). It has been shown that the mussel beds process large amounts of particulate matter and are significant sources of inorganic nutrients (Prins \& Smaal 1990, 1994, Dame et al. 1991). In this study, we present the results of in situ measurements of the exchange of particulate material between the water column and an intertidal mussel bed. Filtration rates of the mussel bed are compared to rates determined with individual mussels under semi-natural conditions. We test the hypothesis that the net flux of material is determined by mussel filtration and abiotic conditions, and cannot be predicted from data on bivalve grazing rates and in situ particle concentrations only. Net fluxes of material between the water column and the bivalves are related to abiotic factors.

\section{MATERIAL AND METHODS}

In situ experiments. Material exchange between a mussel bed and the water column was measured with a Benthic Ecosystem Tunnel. The tunnel was made of Plexiglas, had a total length of $12 \mathrm{~m}$, and a width of $0.8 \mathrm{~m}$. The top of the tunnel was 40 to $45 \mathrm{~cm}$ above the sediment. Water was sampled at either end of the tunnel, at a height of $5 \mathrm{~cm}$ above the mussel bed. The length of the tunnel between sampling points was $9.6 \mathrm{~m}$, the cross-sectional area was $0.225 \mathrm{~m}^{2}$ and the bottom surface between the sampling points was $7.7 \mathrm{~m}^{2}$ A NSW Meerestechnik current speed meter was mounted at the centre of the tunnel, with the sensor at $20 \mathrm{~cm}$ above the bottom. Current speeds were continuously measured with this current meter and data were stored on a datalogger. The tunnel was set up at low tide, with its longitudinal axis parallel to the observed main current direction. Care was taken not to disturb the part of the sediment or mussel bed within the tunnel or in front of both ends of the tunnel. Sampling of the inflow and outflow of the tunnel started as soon as the tunnel was entirely covered by water, and lasted until the tunnel started to emerge again. Water samples were collected with battery-driven pumps, from a ship anchored alongside the tunnel. Water in the tunnel is turbulently mixed at current speeds above $1 \mathrm{~cm} \mathrm{~s}^{-1}$ (Dame \& Dankers 1988, Prins 1996). When current speeds were below $1 \mathrm{~cm} \mathrm{~s}^{-1}$, no sampling was carried out.

Experiments were carried out in 1987 (June and September), 1988 (June and September) and 1989 (April). Some of the results of the 1987 experiments have been reported already (Dame et al. 1991). All measurements were carried out at the same site, near the low tide level at an intertidal mussel bed in the Zandkreek, in the central part of the Oosterschelde estuary (Fig. 1). On 29/30 June 1988 measurements were carried out with 2 tunnels used simultaneously on 2 mussel beds within a distance of $10 \mathrm{~m}$ from each other. Suspended particulate matter (SPM), particulate organic carbon (POC) and chlorophyll a (chl a) concentrations at the inflows of the 2 tunnels were compared by a Wilcoxon paired-samples test, and were identical during both tides. On 6/7 July 1988 a control experiment was carried out with 1 tunnel, to distinguish between effects of mussel bed morphology and effects of mussel activity. One day before the experiment started, all mussels from an area of $12 \times 1 \mathrm{~m}$ were removed and replaced by empty mussel shells. Removal of the mussels resulted in a partial removal of biodeposits accumulated in the mussel bed. This artificial mussel bed had approximately the same shell density as the original mussel bed

All experiments lasted 2 tidal cycles, and water samples were taken every 30 min during the period of submersion $(8$ to $9 \mathrm{~h}$ ) of the tunnel. Due to rough weather conditions, the experiment on 28/29 September 1988 had to be ended after 1 tidal cycle. Samples were collected in polythene bottles, and transported to the laboratory for the determination of SPM, POC, chl $a$ and phaeophytin a. Analytical methods are described by Prins \& Smaal (1994). Chl a data were converted to phytoplankton carbon using carbon:chlorophyll ratios 
determined in samples collected every 2 wk at 2 monitoring stations in the Oosterschelde. In the latter samples, phytoplankton biomass was determined from cell counts and volume measurements, and chl a was determined by HPLC (Wetsteyn \& Kromkamp 1994, Bakker unpubl. obs.). The carbon:chlorophyll ratios varied between our experiments from 10 to 40

After each experiment mussel biomass was determined by taking six $0.0177 \mathrm{~m}^{2}$ cores from the mussel bed. All macrobenthos were counted, and biomass was determined as ash-free dry weight (AFDW) (Prins \& Smaal 1994). The median length of the mussels in the mussel bed varied between 29 and $43 \mathrm{~mm}$. Mussel biomass in the experiments ranged from 891 to $2187 \mathrm{~g} \mathrm{AFDW} \mathrm{m}^{-2}$ (Table 1). Other species formed a small fraction (max. 12\%) of total macrobenthic biomass.

Fluxes of particulate material between the mussel bed and the water column were calculated from the

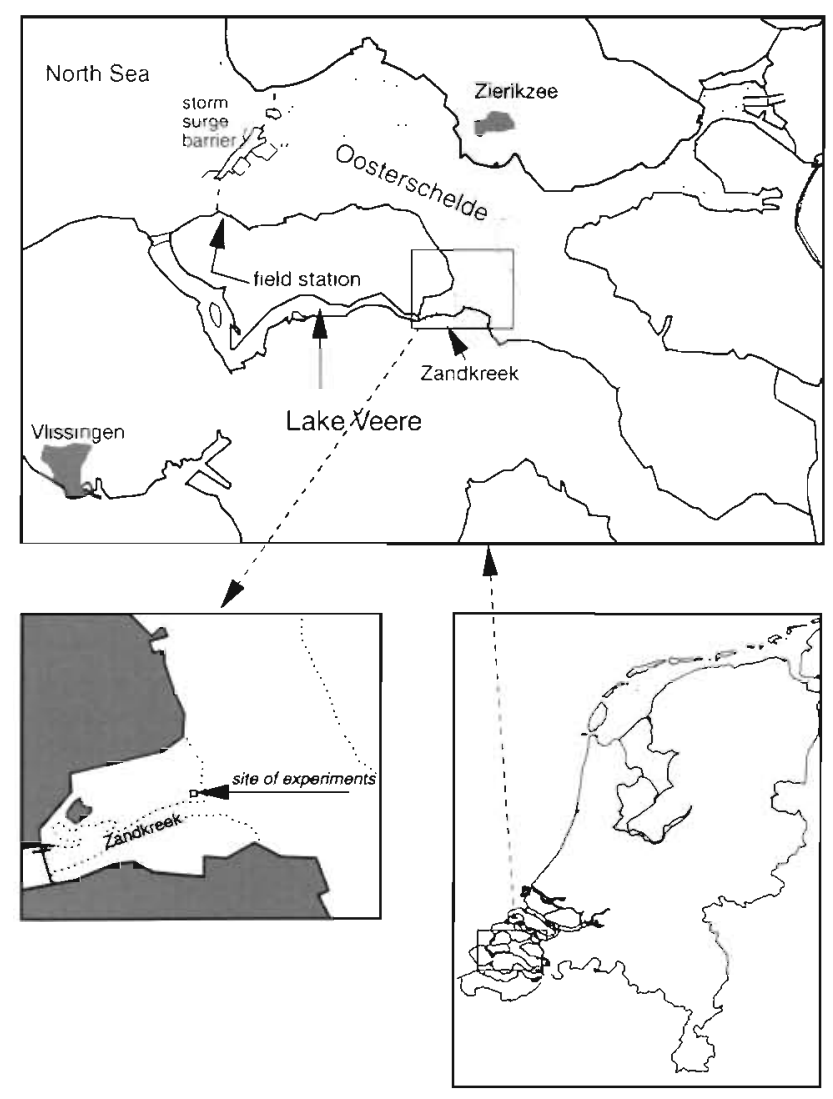

Fig. 1. Map of the Oosterschelde estuary, SW Netherlands. Locations of the in situ experiments in the Zandkreek and of the field station are indicated. In the detailed map of the Zandkreek, light shaded areas are tıdal flats
Table 1. Abundance, median length and ash-free dry weight (AFDW) of the mussels in the mussel bed, and total macrobenthos blomass. (A, B) Values for 2 replicate tunnels

\begin{tabular}{|c|c|c|c|c|}
\hline Date & $\begin{array}{c}\text { Numbers } \mathrm{m}^{-2} \\
(\text { mean } \pm \mathrm{SD})\end{array}$ & $\begin{array}{l}\text { Median } \\
\text { length } \\
(\mathrm{mm})\end{array}$ & $\begin{array}{l}\text { AFDW } \\
\text { mussels } \\
\left(\mathrm{g} \mathrm{m}^{-2}\right)\end{array}$ & $\begin{array}{c}\text { Total AFDW } \\
\text { macrobenthos } \\
\left(\mathrm{g} \mathrm{m}^{-2}\right)\end{array}$ \\
\hline 10/11 Jun 1987 & $1458 \pm 269$ & 42 & 891 & 1009 \\
\hline 16/17 Sep 1987 & $1779 \pm 284$ & 43 & 1273 & 1382 \\
\hline 8/9 Jun 1988 & $3349 \pm 933$ & 42 & 2187 & 2315 \\
\hline 29/30 Jun 1988 (A) & $2852 \pm 825$ & 29 & 1448 & 1534 \\
\hline 29/30 Jun 1988 (B) & $3396 \pm 608$ & 39 & 2147 & 2270 \\
\hline $28 / 29$ Sep 1988 & $2599 \pm 1205$ & 37 & 1721 & 1815 \\
\hline 12/13 Apr 1989 & $6497 \pm 1004$ & 32 & 1206 & 1217 \\
\hline 26/27 Apr 1989 & $4680 \pm 1178$ & 32 & 1569 & 1659 \\
\hline
\end{tabular}

difference between inflow and outflow concentrations and the flux of water through the tunnel. The flux of water was calculated from current velocity distributions observed in the tunnel and the current speeds measured (Prins 1996). For each tidal cycle, inflow and outflow particle concentrations were compared with a Wilcoxon signed-ranks test. Fluxes were denoted as significant when the difference between inflow and outflow concentrations was significant. Clearance rates (volume of water swept clear of particles) were estimated from the difference between inflow and outflow concentrations of chl a. Assuming an equal distribution of the mussels in the tunnel and a constant filtering rate during the sampling period (ca $5 \mathrm{~min}$ ), the concentration of particulate matter in the water flowing through the tunnel will decrease exponentially. The clearance rate of the mussel bed $\left(C R_{\text {bed }}\right.$, in $\mathrm{m}^{3} \mathrm{~m}^{-2}$ $\mathrm{h}^{-1}$ ) could be calculated from the inflow and outflow concentrations $\left(C_{\text {in }}\right.$ and $\left.C_{\text {oul }}\right)$, the water flow through the tunnel $(Q)$, and the surface of the mussel bed between the sampling points $(A)$ with the following formula (Prins et al. 1994)

$$
C R_{\text {bed }}=\ln \left(\frac{C_{\text {in }}}{C_{\text {oul }}}\right) \cdot \frac{Q}{A}
$$

In order to enable a comparison between the observed in situ clearance rates and laboratory data on mussel clearance rates, the in situ rates were standardized to rates for a mussel of $1 \mathrm{~g}$ AFDW. Clearance rate is an allometric function of body weight $\left(C R=a \cdot W^{b}\right.$; Bayne et al. 1976). As the mussel population consisted of a range of size classes, clearance rates were standardized by dividing the observed rates by the metabolic mussel biomass. The metabolic biomass $B_{\mathrm{m}}$ (in g AFDW $\mathrm{m}^{-2}$ ) was calculated from the numbers $\left(\mathrm{n}_{l}\right)$ and individual weights $\left(W_{i}\right)$ of the mussels of each size class $i$ :

$$
B_{\mathrm{m}}=\sum\left(\mathrm{n}, W_{l}^{b}\right)
$$


The value of the weight exponent $b$ is 0.67 (Jones et al 1992).

In a number of observations chl a concentrations were close to or below the detection limit $\left(<0.20 \mathrm{\mu g} \mathrm{I}^{-1}\right)$, and these data were not included.

Laboratory experiments. After each field experiment a random sample of 14 to 25 mussels from the mussel bed was transported to the RIKZ field station (Fig. 1). After acclimatization in running seawater for $24 \mathrm{~h}$, individual mussels were put into flow-through chambers $(0.3$ l) with natural seawater pumped through the chambers at a rate of 5 to $6 \mathrm{l} \mathrm{h}^{-1}$. In- and outflows of the chambers were sampled after another $24 \mathrm{~h}$, and particle concentrations were measured with a Coulter Counter, model Industrial D. Clearance rates (in $\mathrm{l} \mathrm{h}^{-1}$ ) of the mussels were calculated from the following formula (Hildreth \& Crisp 1976):

$$
C R=F \frac{C_{1}-C_{2}}{C_{2}}
$$

where $C_{1}=$ outflow concentration of a control chamber (without mussels), $C_{2}=$ outflow concentration of the mussel chamber, and $F=$ flow rate through the chamber

After clearance rates were measured, individual ashfree dry weights were assessed, and individual clearance rates were recalculated to rates per unit body weight by dividing the individual clearance rates by the metabolic weight (AFDW ${ }^{b}$ ) of the individual, using the weight exponent $b=0.67$.

Assessment of wind influence on particulate matter resuspension. Two methods were used to analyze the effect of wind on sediment resuspension and on SPM composition. First, we looked at correlations between the concentrations of seston components (SPM, POC and chl a) and seston composition (expressed as POC/SPM, chl a/SPM and phaeophytin a/chl a ratios) on the one hand, and wind speed on the other hand. To account for the differences in seston concentration and composition between the experiments, we standardized the values of the parameters by calculating the deviation from the median value for each tidal cycle. At the site of our experiments, fetch (the distance the wind blows over open water) was long $(>6500 \mathrm{~m}$ ) for wind directions between $30^{\circ}$ and $110^{\circ}$. All other wind directions had smaller fetch $(<2500 \mathrm{~m})$. Therefore, we did the correlation analysis separately for winds with a long and winds with a short fetch.

The second method determined a threshold value for the wind speed above which resuspension might occur It was shown by Carper \& Bachmann (1984) that sediment resuspension may occur when the base of a wave extends to the bottom of a water column. The wave base is assumed to be one-half of the wavelength, and when wavelength $L$ is more than twice the water depth $h$ the wave is said to 'feel the bottom' The wavelength of a wave is related to its period, and wave period $I$ can be estimated from wind velocity $U$ and fetch $F$ by the following empirical relation (CERC 1977):

$$
\frac{g T}{2 \pi \cdot U}=1.20 \tanh \left[0.077\left(\frac{g \cdot F}{U^{2}}\right)^{0.25}\right]
$$

where $g$ is the gravitational constant $\left(9.8 \mathrm{~m} \mathrm{~s}^{-2}\right)$

Wavelength (in $\mathrm{m}$ ) can be calculated from:

$$
L=\frac{g \cdot T^{2}}{2 \pi}
$$

The wind speed threshold above which wind-waves may induce resuspension is the wind speed where $L / h>2$. Eqs. (4) \& (5) indicate that wavelength is a function of wind speed and fetch length. Water depth varies during the tidal cycle, leading to a changing wind speed threshold during the tidal cycle. Hourly means for wind speed $U$ were used, and hourly intervals for the determination of wavelength $L$ and water depth $h$.

Data on wind speed and wind direction cluring our in situ experiments were supplied by the Royal Netherlands Meteorological Institute (KNMI), and had been collected by the meteorological station at Vlissingen, which is ca $20 \mathrm{~km}$ from the experimental site. Wind speed was assumed constant for $1 \mathrm{~h}$. Wind velocities below $4 \mathrm{~m} \mathrm{~s}^{-1}$ were assumed to have a small, negligible effect on mixing in the surface water layer (Therriault \& Platt 1981, Demers et al. 1987). Fetch was estimated from navigation charts. Actual water depths at the site of experiments were calculated from water levels measured at a continuous monitoring station in the Oosterschelde estuary near Zierikzee (Fig. 1).

\section{RESULTS}

\section{Tidal variation in concentration and composition of particulate matter}

Quantitative (SPM, POC, chl a) and qualitative (chl a/ SPM seston parameters showed changes by a factor of 2 to 20 during a tidal cycle. Box plots (Tukey 1977) of SPM, POC, chl a and the proportion of chl $a$ in the seston are shown in Fig. 2. POC concentrations showed a stronger correlation with SPM (partial $r=0.711, \mathrm{n}=$ 215 ) than with chl a (partial $r=0.533$ ). In most observations $\mathrm{POC}$ concentrations were between 5 and $20 \%$ of SPM. High chl a concentrations were observed on. 10/11 June 1987 and in April 1989; very low chl a concentrations occurred in June 1988. In most observations phaeophytin a concentrations were below the detection limit. 

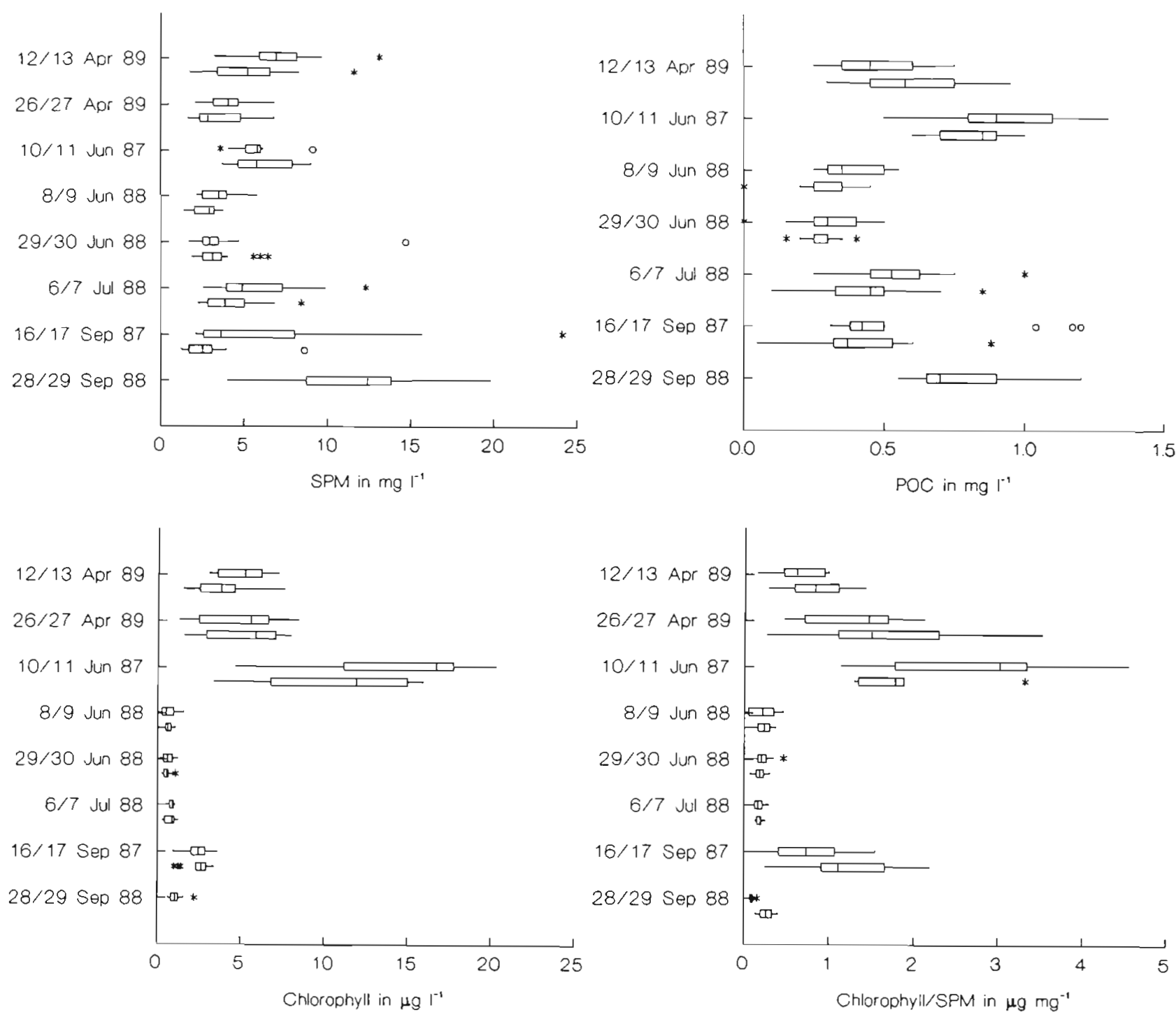

Fig, 2. Box plots of suspended particulate matter (SPM), particulate organic carbon (POC) and chl a concentrations, and chlorophyll/SPM ratio at the inflow of the tunnel. Each data set represents 1 tidal cycle. On 28/29 September 1988 only 1 tidal cycle was sampled

The results showed that chl a concentrations were generally higher during flood tide than during ebb tide (Fig 3). Significantly higher flood concentrations of chl a were observed in 10 of the 15 tidal cycles (MannWhitney $U$-test, $\mathrm{p}<0.05$ ). This pattern was less evident for SPM and POC, with respectively 3 and 4 tidal cycles showing significantly higher flood concentrations.

\section{Wind influence on concentration and composition of particulate matter}

Abiotic conditions during the experiments are summarized in Table 2. During most series of measurements, wind speeds exceeded the threshold for wind- induced resuspension at least during a part of the tidal cycle. Only on 8/9 June 1988, 29/30 June 1988 and 12/13 April 1989 were wind speeds below this threshold during the entire sampling period.

For wind directions with a long fetch, a significant correlation was observed between wind speed and standardized SPM and POC concentrations, POC/ SPM, chl a/SPM and phaeophytin a/chl a ratios during ebb tide (Table 3). SPM, POC and the phaeophytin a/chl a ratio increased at high wind speeds, whereas the POC/SPM and chl a/SPM ratios showed a decrease. During flood tides no significant correlations were observed. For wind directions with a short fetch, the only significant relation was a positive correlation between wind speed and the phaeophytin a/chl a ratio 
$16 / 17$ September 1987

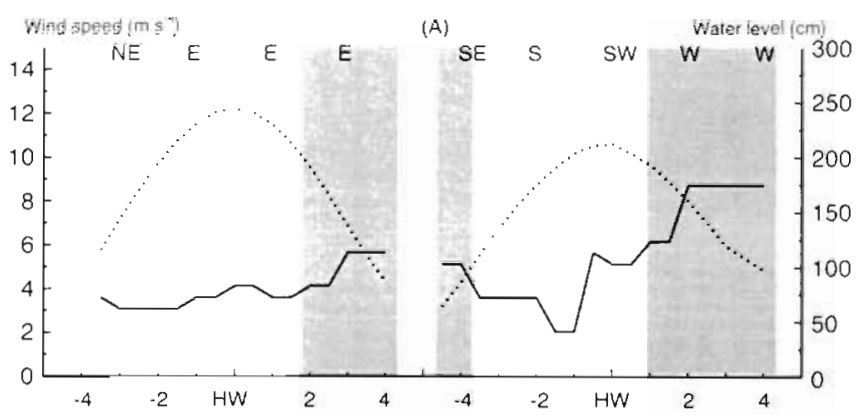

(B)

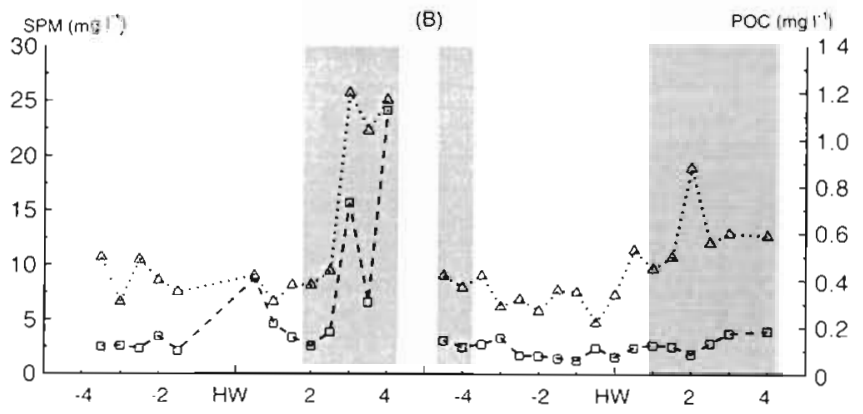

(C)

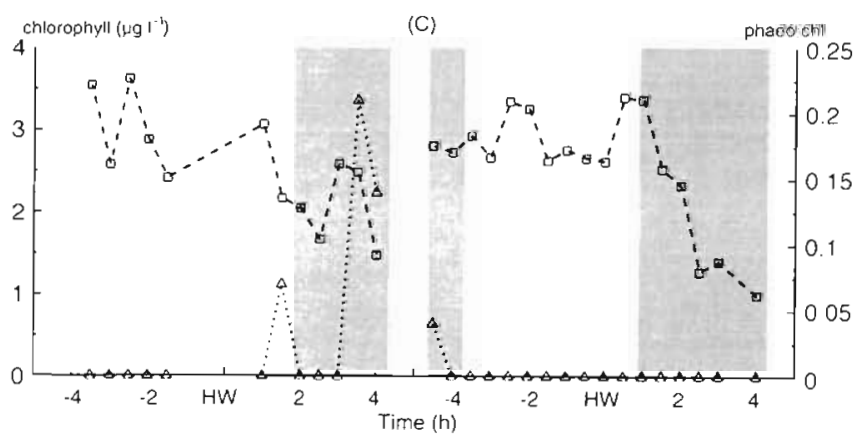

6/7 July 1988

(A)

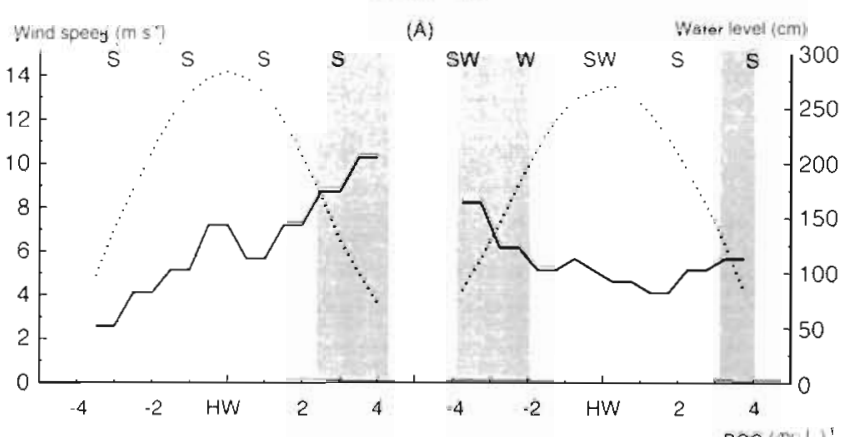

(B)

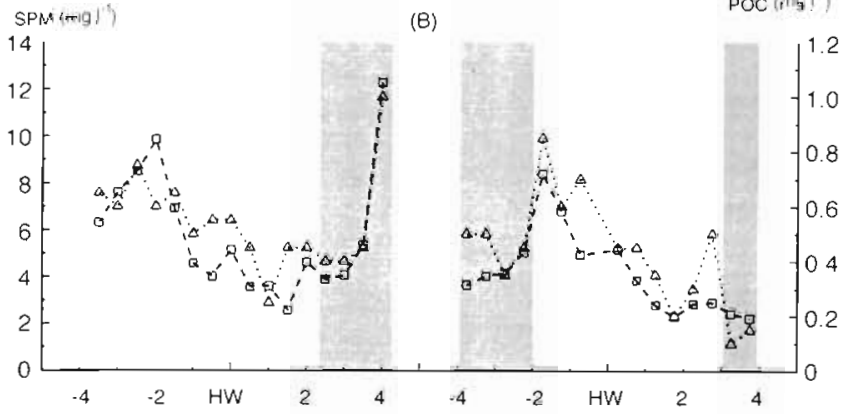

(C) chiorophyll (pgi ')

14
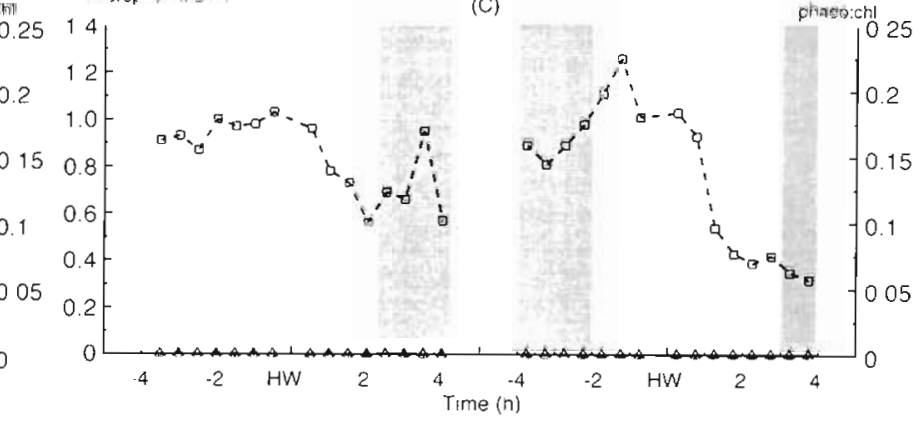

Fig. 3. (A) Water depth (dotted line), wind velocity (solid line) and wind direction, (B) inflow concentrations of SPM ( $\square$, dashed line), POC ( $\triangle$, dotted line), and $(C)$ concentration of chl $a(\square$, dashed line) and phaeophytin a/chI $a$ ratio $(\Delta$, dotted line) during 2 consecutive tidal cycles on $16 / 17$ September 1987 and $6 / 7$ July 1988 . The horizontal axis gives time in hours before or after highwater slack (HW). The shaded area indicates periods with wind speeds above the wind speed threshold for resuspension (see text). Note differences in scale between the 2 dates

during ebb tide. SPM, POC and pigment inflow concentrations during 2 experiments with high wind speeds are shown in Fig. 3. With some exceptions, wind velocities above the wind speed threshold for resuspension coincided with increases in SPM, POC and the phaeophytin/chl ratio during ebb tides. Slight increases in chl a concentrations at high wind speeds were observed on 16/17 September 1987 and 6/7 July 1988. In contrast, no increases in SPM, POC and pigment ratio were observed during the second tidal cycle on 17 September 1987 when westerly winds (with a short fetch) dominated, and during the second tidal cycle on 6/7 July 1988 when wind speed exceeded the threshold during a short period at the end of the tidal cycle only. No effect of wind on SPM, POC and pigment ratios was observed during flood tides.

\section{Fluxes of particulate matter}

Wilcoxon's test comparing inflow and outflow concentrations showed that in most tidal cycles a significant decrease in phytoplankton concentrations occurred as the water flowed through the tunnel. No significant difference between inflow and outflow chl a concentration was observed in the control experiment (Table 4). Fewer tidal cycles showed significant changes in SPM or POC, but calculated fluxes of SPM and POC showed that uptake dominated in most tidal cycles. The control experiment showed a decrease of SPM and POC concentrations (Table 4).

Material fluxes were significantly correlated with inflow concentrations in the observations for which wind speeds were below the wind speed threshold 
(SPM: $\mathrm{r}=0.412, \mathrm{p}<0.001, \mathrm{n}=176$ POC: $r=0.595, p<0.001, n=143$ ). A number of observations at higher wind speeds clearly deviated from this pattern, with often large quantities of material resuspended and exported from the mussel bed (Fig. 4A, B). There was no correlation between inflow concentrations and fluxes of SPM and POC at higher wind speeds. Chl a fluxes showed a high correlation with inflow concentrations ( $\mathrm{r}=$ $0.872, \mathrm{p}<0.001, \mathrm{n}=175$ ) at wind speeds below the wind speed threshold. Wind speeds above the wind speed threshold only occasionally caused resuspension of chl a on the mussel bed (Fig. 4C). In the experiment on 29 June 1988 small differences were observed between the fluxes measured with the 2 tunnels, but these differences were not significant (ANCOVA, $p>0.05$ ).

\section{Composition of fluxes}

The proportion of phytoplankton carbon in the total amount of $\mathrm{POC}$ in the water column was below $10 \%$ in most of our experiments. In June 1987, during a diatom bloom, phytoplankton contributed ca $40 \%$ to POC. The contribution of phytoplankton carbon to the net carbon flux to the mussel bed was much higher than the proportion of phytoplankton-C in water column POC in all tidal cycles, with the exception of one tidal cycle in June 1987 when phytoplankton concentrations in the water column were very high (Fig. 5). In the data presented in Fig. 5, observations done at wind speeds above the wind speed threshold were not included, so the proportionally higher uptake of phytoplankton by the mussel bed was not due to wind-induced export of POC. In 3 tidal cycles even a net release of POC was observed simultaneously with an uptake of phytoplankton-C.

\section{In situ and laboratory clearance rates}

Clearance rates were calculated from the difference between inflow and outflow concentrations of chl a. As high wind velocities could induce resuspension and mask the effects of mussel filtration, observations made at wind speeds above the wind speed threshold were not included in the calculation of clearance rates. In several observations in June $1988 \mathrm{chl}$ a inflow or outflow concentrations were close to or below the detection limit, and clearance rates could not be determined accurately from these data sets. In situ mea- sured clearance rates of the mussel bed varied between 1.3 and $7.1 \mathrm{~m}^{3} \mathrm{~m}^{-2} \mathrm{~h}^{-1}$ (Table 5).

Within a tidal cycle, no consistent differences in clearance rates were observed between flood and ebb tide, or in relation to changes in seston quantity or quality. Mussel bed clearance rates measured with the 2 tunnels on 29 June 1988 were similar, in spite of marked differences in mussel biomass

Mussel bed clearance rates were recalculated to an individual rate per unit body weight, and compared to the results of clearance rate measurements with individual mussels under semi-natural conditions in the field station. In most cases, the differences between in situ measured clearance rates and rates from the laboratory experiments were not significant. One tunnel on 29/30 June 1988 gave a significantly lower estimate of in situ clearance rate. Results from the June 1987 experiment showed significantly higher in situ clearance rates (Table 5).

Table 3. Spearman rank correlation coefficients of relation between wind speed and seston concentration and composition during ebb tides. ${ }^{p} p<0.05 ;{ }^{\cdots} p<0.01$; ns: not significant

\begin{tabular}{|lcc|}
\hline & $\begin{array}{c}\text { Long fetch } \\
\text { (wind direction } \\
\left.30^{\circ}-110^{\circ}\right)\end{array}$ & $\begin{array}{c}\text { Short fetch } \\
\text { (all other wind } \\
\text { directions })\end{array}$ \\
\hline SPM & $0.319^{\circ}$ & $0.114^{\mathrm{ns}}$ \\
POC & $(\mathrm{n}=34)$ & $(\mathrm{n}=92)$ \\
& $0.307^{*}$ & $-0.013^{\mathrm{ns}}$ \\
Chl a & $(\mathrm{n}=34)$ & $(\mathrm{n}=77)$ \\
POC/SPM & $-0.151^{\mathrm{ns}}$ & $-0.005^{\mathrm{ns}}$ \\
& $(\mathrm{n}=33)$ & $(\mathrm{n}=91)$ \\
Chl a/SPM & $-0.401^{\circ}$ & $0.069^{\mathrm{ns}}$ \\
Phaeophytin a/chl $a$ & $(\mathrm{n}=34)$ & $(\mathrm{n}=74)$ \\
& $-0.544^{*}$ & $-0.040^{\mathrm{ns}}$ \\
& $(\mathrm{n}=33)$ & $(\mathrm{n}=90)$ \\
& $0.520^{\circ}$ & $0.282^{*}$ \\
& $(\mathrm{n}=33)$ & $(\mathrm{n}=88)$ \\
\hline
\end{tabular}


Table 4. Fluxes of suspended particulate matter (SPM), particulate organic carbon (POC) and phytoplankton expressed as chl a and carbon (Phyto-C). Values are average fluxes per tidal cycle \pm standard error Positive values indicate uptake by the mussel bed, negative values indicate release. $(A, B)$ Values for 2 replıcate tunnels. On 28/29 September 1988 only 1 tidal cycle was sampled. Results of a Wilcoxon test companng inflow and outflow concentrations are indicated: $p<0.05, \cdots p<0.01, \cdots p<0.001$; nd: not determined

\begin{tabular}{|c|c|c|c|c|c|c|c|}
\hline Date & $\begin{array}{c}\text { SPM } \\
\left(g \mathrm{~m}^{-2} \mathrm{~h}^{-1}\right)\end{array}$ & $\mathrm{n}$ & $\begin{array}{c}\text { POC } \\
\left(\mathrm{g} \mathrm{m}^{-2} \mathrm{~h}^{-1}\right)\end{array}$ & $n$ & $\begin{array}{c}\mathrm{Chla} \\
\left(\mathrm{mg} \mathrm{m}^{-2} \mathrm{~h}^{-1}\right)\end{array}$ & $\begin{array}{c}\text { Phyto-C } \\
\left(\mathrm{g} \mathrm{m}^{-2} \mathrm{~h}^{-1}\right)\end{array}$ & $\mathrm{n}$ \\
\hline \multirow[t]{2}{*}{ 10/11 Jun 1987} & $\begin{array}{r}5.5 \\
\pm 8.5\end{array}$ & 9 & $\begin{aligned} & 2.73 \cdot \\
\pm & 0.74\end{aligned}$ & 10 & $\begin{array}{l}35.8 \cdot \\
\pm 6.05\end{array}$ & $\begin{array}{l}0.991 \cdots \\
\pm 0.168\end{array}$ & 12 \\
\hline & $\begin{array}{r}-44.5 \\
\pm 32.7\end{array}$ & 8 & $\begin{array}{l}-0.65 \\
\pm 1.66\end{array}$ & 8 & $\begin{aligned} & 23.6 \\
\pm & 11.05\end{aligned}$ & $\begin{array}{r}0.654 \\
\pm 0.306\end{array}$ & 7 \\
\hline \multirow[t]{2}{*}{ 16/17 Sep 1987} & $\begin{array}{l}-25.4 \\
\pm 13.7\end{array}$ & 12 & $\begin{array}{l}-0.94 \\
\pm 0.54\end{array}$ & 12 & $\begin{array}{r}3.1^{\circ} \\
\pm 1.37\end{array}$ & $\begin{array}{c}0.063^{\circ} \\
\pm 0.028\end{array}$ & 12 \\
\hline & $\begin{array}{l}-1.74 \\
\pm 2.09\end{array}$ & 17 & $\begin{array}{r}0.24 \\
\pm 0.28\end{array}$ & 17 & $\begin{aligned} & 4.5 \cdots \\
\pm & 0.84\end{aligned}$ & $\begin{array}{c}0.092 \cdots \\
\pm 0.017\end{array}$ & 17 \\
\hline \multirow[t]{2}{*}{ 8/9 Jun 1988} & $\begin{array}{r}8.0 \\
\pm 5.9\end{array}$ & 13 & $\begin{array}{r}0.17 \\
\pm 0.30\end{array}$ & 13 & $\begin{aligned} & 2.6 \\
\pm & 1.48\end{aligned}$ & $\begin{array}{r}0.105 \\
\pm 0.059\end{array}$ & 13 \\
\hline & $\begin{array}{r}5.5^{\circ} \\
\pm 2.2\end{array}$ & 15 & $\begin{array}{r}0.48 \\
\pm 0.38\end{array}$ & 13 & $\begin{array}{c}2.3 \\
\pm 1.09\end{array}$ & $\begin{array}{r}0.090 \\
\pm 0.043\end{array}$ & 15 \\
\hline \multirow[t]{2}{*}{ 29/30 Jun $1988(A)$} & $\begin{aligned} & 4.8^{\circ} \\
\pm & 2.0\end{aligned}$ & 16 & $\begin{array}{r}0.36 \\
\pm 0.46\end{array}$ & 16 & $\begin{array}{r}2.1 \% \\
+0.54\end{array}$ & $\begin{aligned} & 0.040^{\circ} \\
\pm & 0.010\end{aligned}$ & 16 \\
\hline & $\begin{array}{r}12.9 \\
\pm 7.5\end{array}$ & 15 & $\begin{array}{r}0.21 \\
\pm 0.32\end{array}$ & 13 & $\begin{array}{r}2.5 \% \\
\pm 0.68\end{array}$ & $\begin{array}{c}0.047^{\cdots} \\
\pm 0.013\end{array}$ & 15 \\
\hline \multirow[t]{2}{*}{ 29/30 Jun 1988 (B) } & $\begin{array}{r}3.0 \\
\pm 5.3\end{array}$ & 18 & $\begin{array}{l}-0.68^{\circ} \\
\pm 0.29\end{array}$ & 16 & $\begin{array}{c}1.2 \\
\pm 0.57\end{array}$ & $\begin{array}{r}0.024 \\
\pm 0.011\end{array}$ & 18 \\
\hline & $\begin{aligned} & 6.2 \cdots \\
\pm & 1.4\end{aligned}$ & 14 & $\begin{array}{r}0.25 \\
\pm 0.19\end{array}$ & 11 & $\begin{aligned} & 2.1 \cdots \\
\pm & 0.56\end{aligned}$ & $\begin{aligned} & 0.040 \cdots \\
\pm & 0.011\end{aligned}$ & 14 \\
\hline 28/29 Sep 1988 & $\begin{array}{r}1.0 \\
\pm 14.2\end{array}$ & 17 & $\begin{array}{r}0.84 \\
\pm 0.64\end{array}$ & 16 & $\begin{array}{r}1.6^{\circ} \\
\pm 0.61\end{array}$ & $\begin{array}{c}0.051^{\circ} \\
\pm 0.019\end{array}$ & 17 \\
\hline \multirow[t]{2}{*}{ 12/13 Apr 1989} & $\begin{array}{r}30.4 \\
\pm 15.3\end{array}$ & 17 & $\begin{array}{r}0.71 \\
\pm 0.96\end{array}$ & 16 & $\begin{array}{l}22.8 \cdots \\
\pm 3.88\end{array}$ & $\begin{aligned} & 0.203 \cdots \\
\pm & 0.035\end{aligned}$ & 17 \\
\hline & $\begin{array}{l}19.0^{\cdots} \\
\pm 4.9\end{array}$ & 18 & $\begin{array}{r}1.49 \\
\pm 0.36\end{array}$ & 17 & $\begin{array}{l}15.9 \cdots \\
\pm 2.32\end{array}$ & $\begin{array}{c}0.141 \cdots \\
\pm 0.021\end{array}$ & 18 \\
\hline \multirow[t]{2}{*}{ 26/27 Apr 1989} & $\begin{array}{r}17.6 \\
\pm 12.4\end{array}$ & 15 & nd & & $\begin{array}{l}20.0 \cdots \\
\pm 4.41\end{array}$ & $\begin{array}{l}0.330 \cdots \\
\pm 0.073\end{array}$ & 15 \\
\hline & $\begin{array}{l}22.2^{\circ} \\
\pm 9.0\end{array}$ & 16 & nd & & $\begin{array}{l}26.1 \cdots \\
\pm 5.83\end{array}$ & $\begin{array}{c}0.430^{\cdots} \\
\pm 0.096\end{array}$ & 15 \\
\hline \multirow[t]{2}{*}{$\begin{array}{l}6 / 7 \mathrm{Jul} 1988 \\
\text { (control) }\end{array}$} & $\begin{aligned} & 8.9 \cdot \cdot \\
\pm & 5.5\end{aligned}$ & 16 & $\begin{aligned} & 1.10^{\circ} \\
\pm & 0.58\end{aligned}$ & 16 & $\begin{array}{l}-0.1 \\
+0.82\end{array}$ & $\begin{array}{l}-0.001 \\
\pm 0.018\end{array}$ & 15 \\
\hline & $\begin{array}{l}11.5^{\circ} \\
\pm 4.3\end{array}$ & 15 & $\begin{array}{r}0.97 \\
\pm 0.73\end{array}$ & 13 & $\begin{array}{c}0.8 \\
\pm 0.42\end{array}$ & $\begin{array}{r}0.017 \\
\pm 0.009\end{array}$ & 15 \\
\hline
\end{tabular}

\section{DISCUSSION}

\section{Tidal variation in supply of particulate matter and phytoplankton to the mussel bed}

Mussels live in a highly dynamic environment with respect to the quantity of the particulate matter in the water column and the quality of the seston as a food source. Our results showed that both the quantity and the quality of the SPM could vary considerably within 1 tidal cycle, with changes within a tidal cycle being as large as (seasonal) differences between experiments. The large, short-term variability in both quantity and quality of the food for bivalve suspension feeders is typical of estuarine environments (e.g. Cadée 1982, Berg \& Newell 1986, Smaal et al. 1986, Fréchette et al. 1989, Asmus et al. 1990, Fegley et al. 1992). 

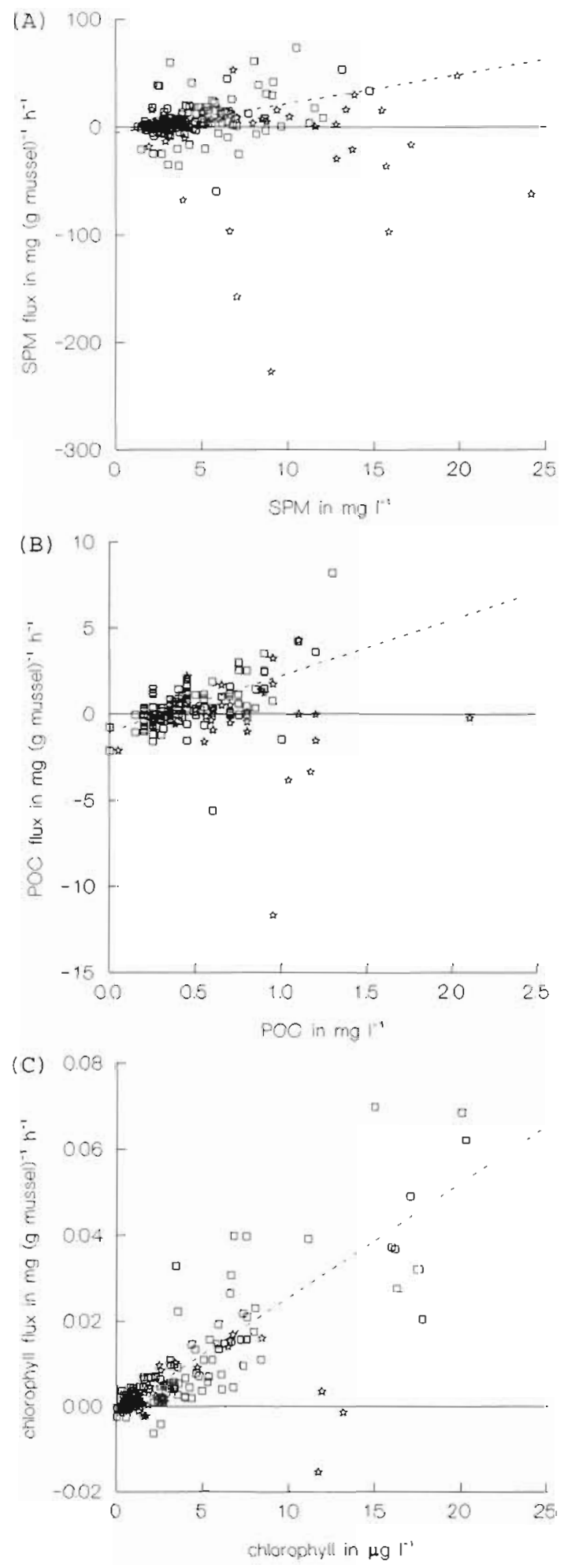

Fig. 4. Weight-specific fluxes of (A) suspended particulate matter, (B) particulate organic carbon and (C) chl $a$ in relation to the inflow concentrations. Open squares and regression line give results with wind speeds below the resuspension threshold, stars give results with wind speeds above the threshold. Positive values indicate uptake by the mussel bed, negative values indicate export from the mussel bed

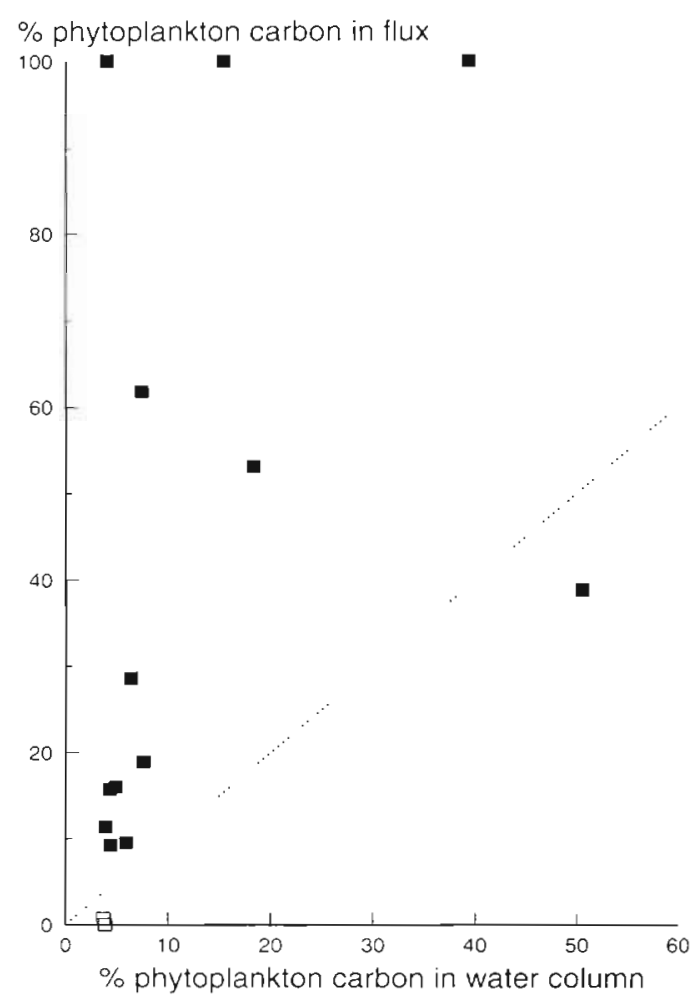

Fig. 5. Proportion of phytoplankton carbon in POC flux to the mussel bed compared to the contribution of phytoplankton to $\mathrm{POC}$ in the water column. Each data point gives the average composition during 1 tidal cycle, excluding observations with wind speeds above the resuspension threshold. ( $\square$ ) Results of the control experiment. The dotted line indicates equal proportions

Depletion of food from the water column by the zoobenthos on a tidal flat is a regularly occurring phenomenon (Carlson et al. 1984, Kamermans 1994), leading to lower concentrations during ebb. In our experiments, the tidal variation in seston concentrations and composition was related to depletion by mussel beds: water from deep tidal channels flowed across the intertidal area during flood tide. After high water slack, the current direction was reversed and water flowing across the intertidal mussel bed drained from an extensive area of intertidal flats (mainly mussel lots). Consequently, during ebb tide chl a concentrations were generally lower than during flood, and lowest concentrations were observed at the end of the ebb tide (Fig. 3).

\section{Wind influence on supply of particulate matter and phytoplankton to the mussel bed}

Wind-induced resuspension has been shown to increase SPM concentrations on a short time scale in 
Table 5. Clearance rates, measured in situ from chl a concentrations, and clearance rates measured in the field station. Individual rates were standardized to rates for a mussel of $1 \mathrm{~g}$ AFDW. Values are means \pm standard error. (A, B) Values for 2 replicate tunnels. :Significantly different from lab results $(t$-test, $p<0.05)$

\begin{tabular}{|c|c|c|c|c|c|}
\hline \multirow[t]{2}{*}{ Date } & \multicolumn{3}{|c|}{ In situ clearance rates } & \multicolumn{2}{|c|}{ Laboratory clearance rates } \\
\hline & $\mathrm{n}$ & $\left(m^{3} m^{-2} h^{-1}\right)$ & $\left(1 \mathrm{~h}^{-1} \mathrm{~g} \mathrm{AFDW}^{-1}\right)$ & & $\left(\mathrm{l} \mathrm{h}^{-1} \mathrm{~g} \mathrm{AFDW}^{-1}\right)$ \\
\hline $10 / 11$ Jun 1987 & 12 & $5.2 \pm 1.35$ & $5.3^{\bullet}$ & 14 & $3.2 \pm 0.40$ \\
\hline $15 / 16$ Sep 1987 & 16 & $1.6 \pm 0.31$ & 1.3 & & \\
\hline $8 / 9$ Jun 1988 & 20 & $5.8 \pm 1.83$ & 2.4 & 14 & $2.7 \pm 0.40$ \\
\hline \multirow[t]{2}{*}{ 29/30 Jun 1988 (A) } & 29 & $4.0 \pm 0.76$ & 2.6 & & \\
\hline & & & & 14 & $3.7 \pm 0.36$ \\
\hline 29/30 Jun 1988 (B) & 20 & $3.2 \pm 0.70$ & $1.3^{\circ}$ & & \\
\hline 28/29 Sep 1988 & 2 & $1.3 \pm 0.70$ & 0.7 & 14 & $1.6 \pm 0.24$ \\
\hline 12/13 Apr 1989 & 35 & $7.1 \pm 0.60$ & 3.4 & & \\
\hline 26/27 Apr 1989 & 23 & $5.0 \pm 0.93$ & 2.3 & 22 & $4.3 \pm 0.87^{\mathrm{a}}$ \\
\hline Measured on $19 \mathrm{~A}$ & & & & & \\
\hline
\end{tabular}

shallow coastal waters (Shideler 1984, Gabrielson \& Lukatelich 1985, Demers et al. 1987, Asmus et al. 1990, De Jonge 1992, Arfi et al. 1993). Although our observations were limited to periods with relatively low wind speeds (maximum wind speed $14.9 \mathrm{~m} \mathrm{~s}^{-1}$ ), the results suggested that wave action caused by high wind speeds had a considerable impact on the food supply to the mussel bed during ebb tides (Table 3). High SPM and POC concentrations and increased phaeophytin a/chl a ratios coincided with high wind speeds, and were observed mainly at the end of the ebb tides when the wind speeds were above the calculated threshold for wind-wave resuspension. High phaeophytin a/chl a ratios are often observed in estuarine sediments, and are an indication of the presence of high amounts of algal detritus (Cadée \& Hegeman 1977, Colijn \& Dijkema 1981). The increased phaeophytin a/chl $a$ ratios in our observations showed that significant resuspension of algal detrital matter occurred. This was presumably due to resuspension of mussel biodeposits (cf. Fréchette \& Bourget 1985), During flood tides, wind influence on the composition of the seston was less clear. As discussed above, water came from deep tidal channels during flood and was probably less affected on a short time scale by wind-induced resuspension than the water during ebb, which drained from a shallow, intertidal area.

Due to resuspension, microphytobenthos may form a major contribution to pelagic algal biomass (Baillie \& Welsh 1980, Grant et al. 1990, De Jonge \& Van Beusekom 1992, Kamermans 1994) but this is not a general phenomenon (Fréchette \& Bourget 1985, Fréchette \& Grant 1991, Asmus \& Asmus 1993). The limited resuspension of chl a observed in our experiments indicated that microphytobenthos was a minor food source for the mussels at our study site. In gen- eral, microphytobenthos is assumed to be quantitatively unimportant as a food source for mussels in the Oosterschelde (Smaal \& Van Stralen 1990). This is probably due to the predominance of epipsammic diatoms in the microphytobenthos of the Oosterschelde estuary. These diatoms live closely attached to sediment particles, and are less easily resuspended (Vos et al. 1988)

The potential effect of wind on resuspension of sediments was determined from empirical formulas on the relation between wind speed, fetch and wave characteristics. The formulas used (CERC 1977) have been shown to adequately describe the minimum wind speeds at which resuspension of bottom material may occur in lakes and in shallow estuarine environments (Carper \& Bachmann 1984, Shideler 1984, Demers et al. 1987, Simon 1989, Arfi et al. 1993). For winds with a long fetch, highly significant correlations between wind speed and SPM or POC concentrations or the phaeophytin $a / c h l$ a ratio were observed during ebb. These 3 parameters particularly showed strong increases when wind speeds had exceeded the wind speed threshold calculated according to Carper \& Bachmann (1984), but there was a time lag of 1 to $2 \mathrm{~h}$. between the moment wind speeds exceeded the threshold and the moment resuspension actually was observed (Fig. 3) This may have been due to the high cohesiveness of the sediment at the mussel lots (Nowell et al. 1981) or may point to an overestimation of wind-induced wave action at our study site. For winds with a short fetch, the only significant correlation was the correlation between wind speed and the phaeophytin $a / c h l$ a ratio during ebb. Although wind speeds exceeded the calculated threshold in the second tidal cycle of September 1987, no resuspension was observed (Fig 3). It should be taken into consideration 
that we used wind data obtained from a weather station $20 \mathrm{~km}$ from our study site. Especially for the wind directions with a short fetch, actual wind speeds at the study site may have been reduced due to the proximity of land. This may have resulted in an overestimation of actual wavelengths. Moreover, the empirical formulas to calculate wind-waves do not consider the complex relations between factors like wind, fetch, changing water depths during the tidal cycle and local geomorphology, which all affect wave development. Nevertheless, the observed correlations between high wind speeds and increases in SPM, POC and phaeophytin $a / c h l$ a ratio indicate that wind action may significantly affect food conditions for bivalve suspension feeders in the intertidal on a short time scale.

\section{Filtration activity of the mussel bed}

The changes in chl a concentrations observed in situ with a tunnel are the net result of mussel grazing, sedimentation and resuspension. The control experiment showed that sedimentation of chl a was negligible in the tunnel. Resuspension of chl a mainly occurred in relation to wind-induced turbulence (Fig. 4C). Therefore, we calculated in situ clearance rates for observations at low wind velocities only, and assumed that wind-induced resuspension of chl a was negligible in these observations. Observed clearance rates of the mussel bed varied between 1.3 and $7.1 \mathrm{~m}^{3} \mathrm{~m}^{-2} \mathrm{~h}^{-1}$, depending on biomass and activity of the mussels. Earlier estimates of mussel bed grazing rates based on extrapolation of individual measurements ranged from 3.5 to $5.9 \mathrm{~m}^{3} \mathrm{~m}^{-2} \mathrm{~h}^{-1}$ (Jørgensen 1980, Fréchette et al. 1989). In a 12 mo experiment on a semi-natural mussel bed with a biomass between 600 and $1200 \mathrm{~g}$ AFDW, clearance rates up to $2.7 \mathrm{~m}^{3} \mathrm{~m}^{-2} \mathrm{~h}^{-1}$ were observed (Prins et al. 1994).

With the exception of June 1987, in situ clearance rates were slightly lower than rates estimated in experiments with individual mussels under semi-natural conditions. However, the variation in the estimates of weight-standardized clearance rates was quite large and only the rates observed with tunnel B on $29 / 30$ June 1988 were significantly lower than the rates determined in the field station. On this date in situ chl a concentrations were very low and this reduced the accuracy of the determined clearance rates. Therefore, the low clearance rates observed in tunnel B may be considered an artefact due to the low chl a concentrations.

A number of factors may influence in situ mussel clearance rates. Current velocities above $25 \mathrm{~cm} \mathrm{~s}^{-1}$ have been shown to reduce clearance rates (Wildish \& Miyares 1990). This was probably a minor factor in our experiments, as in less than $3 \%$ of our observations were current velocities higher than $20 \mathrm{~cm} \mathrm{~s}^{-1}$. In our in situ experiments, the mussels were exposed to large, short-term changes in food quantity and quality. Mussels mainly respond to short-term changes in the food supply by varying pseudofaeces production coupled with selection processes, but may also change clearance rates (Bayne 1993, Bayne et al. 1993). Although this adds to the variability observed in the field, it does not necessarily imply lower in situ clearance rates. A physical hindrance of feeding of the mussels at the inner side of mussel patches may cause a reduced overall clearance rate. External pressure on the shells of mussels will impair shell opening, which is a critical factor in controlling pumping rates (Fréchette et al. 1992). Finally, we cannot exclude that some chl $a$, filtered by the mussels, was resuspended again by the tidal currents. This would lead to an underestimation of in situ clearance rates. Still, our data showed that clearance rates, measured in experiments with individual mussels fed with natural seawater, generally agreed with clearance rates observed by in situ measurements, and can be used to estimate grazing rates by mussel beds in the field.

\section{Material exchange between the water column and the mussel bed}

The net fluxes of SPM, POC and phytoplankton carbon observed in our experiments were in the same range as in situ measured fluxes on mussel beds in the Wadden Sea (Dame \& Dankers 1988, Asmus et al. 1990, Dame et al. 1991), Mean SPM uptake in our experiments was equivalent to $118 \mathrm{~g} \mathrm{~m}^{-2} \mathrm{~d}^{-1}$, assuming an inundation time of $18 \mathrm{~h} \mathrm{~d}^{-1}$. This value agreed quite well with estimates of net sedimentation rates on mussel beds in the Oosterschelde (97 to $194 \mathrm{~g} \mathrm{~m}^{-2} \mathrm{~d}^{-1}$; Ten Brinke 1993). We observed a consistent uptake of chl a and a highly significant correlation between water column concentrations of chl a and fluxes from the water column to the mussel bed, at wind speeds below the threshold for resuspension. The fluxes of SPM and POC showed more variability than the chl a fluxes, but still showed a significant correlation with the respective inflow concentrations under calm weather conditions.

In the control experiment, an uptake of SPM and POC was observed. This indicated that some sedimentation of seston particles occurred in the tunnel, probably due to a reduction of the current velocity in the tunnel compared to the water flow outside the tunnel (Prins 1996). No uptake of chl a was observed in the control experiment. The difference in behaviour between SPM and POC on the one hand, and chl $a$ on the 
other hand, suggested that mainly silt or detritus settled in the tumnel in the control experiment. This can be explained by the lower settling velocities of living phytoplankton cells compared to SPM in the Oosterschelde (Ten Brinke 1993) The observed sedimentation in the control tunnel implied that some part of the SPM and POC fluxes, observed in the mussel experiments, may have been due to sedimentation.

Wind-induced turbulence affected the fluxes of particulate material measured with the Benthic Ecosystem Tunnel. Occasionally, we observed high rates of export of SPM and POC from the mussel bed, coinciding with high wind velocities. The tunnel must have diminished the effects of waves on the sediment of the mussel bed, even though the tunnel is made of flexible material. Moreover, our observations were limited to the period when the tunnel was entirely submerged, which means that water depth was more than 0.40 to $0.45 \mathrm{~m}$. At lower water depths, it has been shown that small wavelets near the flood front may cause significant resuspension (Anderson 1980). A flume study on an intertidal mussel bed in the Wadden Sea also showed a predominant export of particulate matter during a moderate gale (maximum wind velocity $10.5 \mathrm{~m} \mathrm{~s}^{-1}$; Asmus et al. 1990). The latter observations and the results from our study show that wind action may be an important factor determining the net flux of particulate matter to and from a mussel bed. High rates of biodeposition during periods of calm weather may alternate with periods when export dominates. It was technically not possible to carry out experiments during gales, so our observations were limited to relatively low wind speeds and water depths of more than $40 \mathrm{~cm}$, and should therefore be considered as a minimum estimate of the exchange processes caused by wind influence.

The consistent uptake of phytoplankton carbon, along with a more erratic pattern of POC uptake, resulted in net carbon fluxes with a much higher proportion of phytoplankton carbon than was to be expected from the seston composition. This was not due to wind-induced resuspension of carbon-rich sediment material, as results presented in Fig. 4 include observations at low wind velocities only. Preferential ingestion of algal material by bivalves will lead to production of pseudofaeces with a relatively low proportion of algae compared to the seston (Kigrboe \& Møhlenberg 1981, Newell \& Jordan 1983, Prins et al. 1991). Pseudofaeces have a very loose structure and a low settling velocity $\left(0.5\right.$ to $1.0 \mathrm{~cm} \mathrm{~s}^{-1}$; Oenema 1988), are ejected into the water current by the mussels, and are probably easily resuspended (Risk \& Moffat 1977. Taghon et al. 1984) and exported from the mussel bed.

In addition to the export of pseudofaeces from the mussel bed, some resuspension of faeces may have occurred in our experiments. There are no literature data on the erodibility of mussel faeces, but freshly egested faecal pellets of deposit feeders are more easily transported than the surrounding sediment (Risk \& Moffat 1977, Taghon et al. 1984). Observations on mussel beds have shown that only 15 to $40 \%$ of the upper layer of the sediment consisted of identifiable faecal pellets, and this was assumed to be due either to resuspension of part of the faeces, or to a rapid degradation of the faeces in the sediment (Ten Brinke et al. 1995). Assuming that the mussels filtered POC at the same rates as chl $a$, it could be calculated from our observations at low wind speeds that approximately $50 \%$ of the POC filtered by the mussels was resuspended and exported from the mussel bed. Therefore, tidal currents play an essential role not only in the supply of food to the mussel beds, but also in the transport of waste products. Wind-induced resuspension will occur more randomly, but the quantitative effects may be much larger.

As a net result of filtration by the mussels and resuspension of biodeposits by tidal currents and wind waves, only a fraction of the SPM filtered by the mussel population was stored as biodeposits in the sediment. Moreover, the proportionally higher net uptake of phytoplankton indicated that the mussels had far more impact on phytoplankton standing stock than on the concentration of SPM in the water column.

\section{Conclusions}

Our observations support the view that mussel beds process large amounts of particulate material. In situ clearance rates generally were comparable to clearance rates measured on individual mussels in a field station. The clearance rates were in the same range as rates used by Smaal et al. (1986) and Van Stralen \& Dijkema (1994), who estimated that the mussel population in the Oosterschelde filters the entire volume of the estuary in less than $10 \mathrm{~d}$. This corroborates the hypothesis that the mussel population in the Oosterschelde has a major effect on phytoplankton biomass (Smaal et al. 1986, Herman \& Scholten 1990).

During periods with low wind speeds, a major part of the POC filtered by the mussels was exported from the mussel bed, probably due to resuspension of faeces and pseudofaeces by tidal currents. In addition, windinduced resuspension caused a significant export of particulate material, mainly SPM and POC. The net result of biofiltration, biodeposition and resuspension processes was a high uptake of phytoplankton by the mussel bed, and a relatively reduced uptake of SPM and POC. Consequently, the mussel bed acted as a selective filter for high quality food material. 
Acknowledgements. We thank P. H. Nienhuis, W. Wolff, F. Colijn, R. F. Dame, W. ten Brinke, A. Langerak and 2 anonymous referees for their comments on the manuscript. We also thank B. Boer, K. de Dreu, H. Hiemstra, C. Joosse, W. Roelse, A. Meijboom, K. Siereveld, J. Zegers and the crews of the MS 'Agger' and MS 'Hontsloo' for technical assistance during the field experiments. The chemical analyses were carried out by the laboratory of RIKZ Middelburg. This research was financed by RIKZ. This is publication no. 2176 of the Netherlands Institute of Ecology, Centre for Estuarine and Coastal Ecology.

\section{LITERATURE CITED}

Anderson FE (1980) The variation in suspended sediment and water properties in the flood-water front traversing the tidal flat. Estuaries 3:28-37

Arfi R, Guiral D, Bouvy M (1993) Wind induced resuspension in a shallow tropical lagoon. Estuar Coast Shelf Sci 36 : $587-604$

Asmus H, Asmus RM (1993) Phytoplankton-mussel bed interactions in intertidal ecosystems. In: Dame RF (ed) Bivalve filter feeders in estuarine and coastal ecosystem processes. NATO ASI Series, Series G, Ecological sciences, Vol 33. Springer-Verlag, Berlin, p 57-84

Asmus H, Asmus R, Reise K (1990) Exchange processes in an intertidal mussel bed: a Sylt-flume study in the Wadden Sea. Ber Biol Anst Helgoland 6:1-79

Asmus RM, Asmus H (1991) Mussel beds: limiting or promoting phytoplankton? J Exp Mar Biol Ecol 148:215-232

Baillie PW, Welsh BL (1980) The effect of tidal resuspension on the distribution of intertidal epipelic algae in an estuary. Estuar Coast Mar Sci 10:165-180

Bayne BL (1993) Feeding physiology of bivalves: time dependence and compensation for changes in food availability. In: Dame RF (ed) Bivalve filter feeders in estuarine and coastal ecosystem processes. NATO ASI Series, Series G, Ecological sciences, Vol 33. Springer-Verlag, Berlin, $p$ $1-24$

Bayne BL, Iglesias JIP, Hawkins AJS, Navarro E, Héral M, Deslous-Paoli JM (1993) Feeding behaviour of the mussel, Mytilus edulis: responses to variations in quantity and organic content of the seston. J Mar Biol Ass UK 73:813-829

Bayne BL, Thompson RJ, Widdows J (1976) Physiology: I. In: Bayne BL (ed) Marine mussels: their ecology and physiology. Cambridge University Press, Cambridge, p 121-206

Berg JA, Newell RIE (1986) Temporal and spatial variations in the composition of seston available to the suspension feeder Crassostrea virginica. Estuar Coast Shelf Sci 23: $375-386$

Cadée GC (1982) Tidal and seasonal variation in particulate and dissolved organic carbon in the Western Dutch Wadden Sea and Marsdiep tidal inlet. Neth $\mathrm{J}$ Sea Res 15 $228-249$

Cadée GC, Hegeman J (1974) Primary production of phytoplankton in the Dutch Wadden Sea. Neth J Sea Res 8 $240-259$

Cadée GC, Hegeman J (1977) Distribution of primary production of the benthic microflora and accumulation of organic matter on a tidal flat area, Balgzand, Dutch Wadden Sea. Neth J Sea Res 11:24-41

Carlson DJ, Townsend DW, Hilyard AL, Eaton JF (1984) Effect of an intertidal mudflat on plankton of the overlying water column. Can J Fish Aquat Sci 41:1523-1528

Carper GL, Bachmann RW (1984) Wind resuspension of sediments in a prairie lake. Can J Fish Aquat Sci 41:1763-1767
CERC (1977) Shore protection manual, Vol 1, 3rd edn. US Army Corps of Engineers, Coastal Engineering Research Centre, Washungton, DC

Cloern JE (1982) Does the benthos control phytoplankton bromass in South San Francisco Bay? Mar Ecol Prog Ser 9 $191-202$

Colijn F, Dijkema KS (1981) Species composition of benthic diatoms and distribution of chlorophyll $a$ on an intertidal flat in the Dutch Wadden Sea. Mar Ecol Prog Ser 4:9-21

Dame RF (1993) The role of bivalve filter feeder material fluxes in estuarine ecosystems. In: Dame RF (ed) Bivalve filter feeders in estuarine and coastal ecosystem processes. NATO ASI Series, Serles G, Ecological sciences, Vol 33. Springer-Verlag, Berlin, p 245-270

Dame RF, Dankers N (1988) Uptake and release of materials by a Wadden Sea mussel bed. J Exp Mar Biol Ecol 118: $207-216$

Dame RF, Dankers N, Prins T, Jongsma H, Smaal A (1991) The influence of mussel beds on nutrients in the Western Wadden Sea and Eastern Scheldt estuaries. Estuaries 14 $130-138$

Dame RF, Spurrier JD, Wolaver TG (1989) Carbon, nitrogen and phosphorus processing by an oyster reef. Mar Ecol Prog Ser 54:249-256

Dame RF, Zingmark RG, Haskin E (1984) Oyster reefs as processors of estuarine materials. J Exp Mar Biol Ecol 83: $239-247$

De Jonge VN (1992) Physical processes and dynamics of microphytobenthos in the Ems estuary (The Netherlands). PhD thesis, University of Groningen

De Jonge VN, Van Beusekom JEE (1992) Contribution of resuspended microphytobenthos to total phytoplankton in the Ems estuary and its possible role for grazers. Neth $J$ Sea Res 30:91-105

Demers S, Therriault JC, Bourget E, Bah A (1987) Resuspension in the shallow sublittoral zone of a macrotidal estuarine environment: wind influence. Limnol Oceanogr 32 $327-339$

Doering $\mathrm{PH}$, Oviatt CA (1986) Application of filtration rate models to field populations of bivalves: an assessment using experimental mesocosms. Mar Ecol Prog Ser 31. $265-275$

Fegley SR, MacDonald BA, Jacobsen TR (1992) Short-term variation in the quantity and quality of seston available to benthic suspension feeders. Estuar Coast Shelf Sci 34: $393-412$

Fréchette M, Aitken AE, Pagé L (1992) Interdependence of food and space limitation of a benthic suspension feeder: consequences for self-thinning relationships. Mar Ecol Prog Ser 83:55-62

Fréchette M, Bourget E (1985) Energy flow between the pelagic and benthic zones: factors controlling particulate organic matter available to an intertidal mussel bed. Can J Fish Aquat Sci 42:1158-1165

Fréchette M, Butman CA, Geyer WR (1989) The importance of boundary-layer flows in supplying phytoplankton to the benthic suspension feeder. Mytilus edulis L. Limnol Oceanogr 34:19-36

Fréchette M, Grant J (1991) An in situ estimation of the effect of wind-driven resuspension on the growth of the mussel Mytilus edulis L. J Exp Mar Biol Ecol 148:201-213

Gabrielson JO, Lukatelich RJ (1985) Wind-related resuspension of sediments in the Peel-Harvey estuarine system. Estuar Coast Shelf Sci 20:135-145

Grant J, Enright CT, Griswold A (1990) Resuspension and growth of Ostrea edulis: a field experiment. Mar Biol 104: $51-59$ 
Haven DS, Morales-Alamo R (1972) Biodeposition as a factor in sedimentation of fine suspended solids in estuaries. Geol Soc Am Mem 133:121-130

Herman PMJ, Scholten H (1990) Can suspension-feeders stabilize estuarine ecosystems? In: Barnes M, Gibson R (eds) Trophic relationships in the marine environment. Aberdeen University Press, Aberdeen, p 104-116

Hildreth DI, Crisp DJ (1976) A corrected formula for calculation of filtration rate of bivalve molluscs in an experimental flowing system. J Mar Biol Ass UK 56:111-120

Hily $C$ (1991) Is the activity of benthic suspension feeders a factor controlling water quality in the Bay of Brest? Mar Ecol Prog Ser 69:179-188

Jones HD, Richards OG, Southern TA (1992) Gill dimensions, water pumping rate and body size in the mussel Mytilus edulis L. J Exp Mar Biol Ecol 155:213-237

Jorgensen BB (1980) Seasonal oxygen depletion in the bottom waters of a Danish fjord and its effect on the benthic community. Oikos 34:68-76

Kamermans P (1994) Similarity in food source and timing of feeding in deposit- and suspension-feedıng bivalves. Mar Ecol Prog Ser 104:63-75

Kiørboe T, Mohlenberg F (1981) Particle selection in suspension-feeding bivalves. Mar Ecol Prog Ser 5:291-296

Newell RIE, Jordan SJ (1983) Preferential ingestion of organic material by the American oyster Crassostrea virginica. Mar Ecol Prog Ser 13:47-53

Nichols FH (1985) Increased benthic grazing: an alternative explanation for low phytoplankton biomass in northern San Francisco Bay during the 1976-1977 drought. Estuar Coast Shelf Sci 21:379-388

Nienhuis PH. Smaal AC (1994) The Oosterschelde estuary (The Netherlands). A case-study of a changing ecosystem. Hydrobiologia 282/283:1-14

Nowell ARM, Jumars PA, Eckman JE (1981) Effects of biological activity on the entrainment of marine sediments. Mar Geol 42:133-153

Oenema O (1988) Early diagenesis in recent fine-grained sediments in the Eastern Scheldt. PhD thesis, University of Utrecht

Prins TC (1996) Bivalve grazing, nutrient cycling and phytoplankton dynamics in an estuarine ecosystem. PhD thesis, University of Wageningen

Prins TC, Dankers N. Smaal AC (1994) Seasonal variation in the filtration rates of a semi-natural mussel bed in relation to seston composition. J Exp Mar Biol Ecol 176:69-86

Prins TC, Smaal AC (1990) Benthic-pelagic coupling: the release of inorganıc nutrients by an intertidal bed of Mytilus edulis. In: Barnes M, Gibson R (eds) Trophic relationships in the marne environment. Aberdeen University Press, Aberdeen, p 89-103

Prins TC, Smaal AC (1994) The role of the blue mussel Mytilus edulis in the cycling of nutrients in the Oosterschelde estuary (The Netherlands). Hydrobiologia 282/ 283:413-429

Prins TC, Smaal AC, Pouwer AJ (1991) Selective ingestion of phytoplankton by the bivalves Mythlus edulis L. and Cerastoderma edule (L.). Hydrobiol Bull 25:93-100

Risk MJ, Moffat JS (1977) Sedimentological significance of fecal pellets of Macoma balthica in the Minas Basin, Bay of

This article was submitted to the editor
Fundy. J Sed Petrol 47:1425-1436

Shıdeler GL (1984) Suspended sediment responses in a winddominated estuary of the Texas Gulf coast. J Sed Petrol $54: 731-745$

Simon NS (1989) Nitrogen cycling between sediment and the shallow-water column in the transition zone of the Potomac river and estuary. II. The role of wind-driven resuspension and adsorbed ammonium. Estuar Coast Shelf Sci 28:531-547

Smaal AC, Prins TC (1993) The uptake of organic matter and the release of inorganic nutrients by bivalve suspension feeder beds. In: Dame RF (ed) Bivalve filter feeders in estuarine and coastal ecosystem processes. NATO ASI Series, Series G, Ecological sciences, Vol 33. SpringerVerlag, Berlin, p 271-298

Smaal AC, Van Stralen M (1990) Average annual growth and condition of mussels as a function of food source. In: McClusky DS, De Jonge VN, Pomfret J (eds) North Sea estuaries interactions. Hydrobiologia 195:179-188

Smaal AC, Verhagen JHG, Coosen J, Haas HA (1986) Interactions between seston quantity and quality and benthic suspension feeders in the Oosterschelde, The Netherlands. Ophelia 26:385-399

Taghon GL, Nowell ARM, Jumars PA (1984) Transport and breakdown of faecal pellets: biological and sedimentological consequences. Limnol Oceanogr 29:64-72

Ten Brinke WBM (1993) The impact of biological factors on the deposition of fine-grained sediment in the Oosterschelde (The Netherlands). PhD thesis, University of Utrecht

Ten Brinke WBM, Augustinus PGEF, Berger GW (1995) Fine-grained sediment deposition on mussel beds in the Oosterschelde (The Netherlands), determined from echosoundings, radio-isotopes, and biodeposition field experiments. Estuar Coast Shelf Sci 40:195-218

Therriault JC, Platt I (1.981) Environmental control of phytoplankton patchiness. Can J Fish Aquat Sci 38:638-641

Tukey JW (1977) Exploratory data analysis. Addison-Wesley Publishing $\mathrm{Co}$, Reading, MA

Van Stralen MR, Dijkema RD (1994) Mussel culture in a changing environment: the effects of a coastal engineering project on mussel culture (Mytilus eduls L.) in the Oosterschelde (S.W. Netherlands). Hydrobiologia 282/283:359-379

Verwey J (1952) On the ecology of distribution of cockle and mussel in the Dutch Waddensea, their role in sedimentation and the source of their food supply. Arch Neerl Zool 10:1.71-239

Vos PC, De Boer PL, Misdorp R (1988) Sediment stabilization by benthic diatoms in intertidal sandy shoals; qualitative and quantitative observations. In: De Boer P, Van Gelder A, Nio SD (eds) Tide-influenced sedimentary environments and facies. Reidel. Dordrorht n 511-576

Wetsteyn LPMJ, Kromkamp JC (1994) Turbidity, nutrients and phytoplankton primary production in the Oosterschelde (The Netherlands) before, during and after a large-scale coastal engineering project (1980-1990) Hydrobiologia 282/283:61-78

Wildish DJ, Miyares MP (1990) Filtration rate of blue mussels as a function of flow velocity: preliminary experments. J Exp Mar Biol Ecol 142:213-219

Manuscript first received: January 10,1996

Revised version accepted: June 14, 1996 